\title{
THE INFLUENCE OF SERVICE QUALITY AND PRICE ON CUSTOMER SATISFACTION AT PT. JURAGAN WIFI INDONESIA
}

\author{
Muhammad Rian Ardianto ${ }^{1}$ \\ ${ }^{1}$ Faculty of Economics, State Univeristy of Jakarta \\ Jakarta, Indonesia \\ rianardian212@gmail.com \\ Dra. Basrah Saidani, M.Si ${ }^{2}$ \\ ${ }^{2}$ Faculty of Economics, State University of Jakarta \\ Jakarta, Indonesia \\ basrah-saidani@unj.ac.id \\ Ika Febrilia, S.E., M.M ${ }^{3}$ \\ ${ }^{3}$ Faculty of Economics, State University of Jakarta \\ Jakarta, Indonesia \\ ikafebrilia@unj.ac.id
}

\begin{abstract}
In 2020, the government's policy that happens to stop the COVID-19 pandemic link by limiting community activities through Learn from Home and Work from Home, which has encouraged an increase in internet use in Indonesia. The rise in internet usage has made the technology industries aware while the humongous growth of demand for internet connection in Indonesia, especially during this pandemic. In 2020, there are four top brand internet service providers (ISPs) based on topbrand-award.com, namely: Indihome by $36.7 \%$, First Media by $23.1 \%$, Biznet by $8.2 \%$, and Indosat M2 by $4.5 \%$. The main objectives of this research study are: First, To determine the influence of Service Quality on Customer Satisfaction of PT Juragan Wifi Indonesia. Second, To assess the impact of Price on customer satisfaction of PT Juragan Wifi Indonesia. The number of respondents of this study where the research was conducted is 100 customers of PT. Juragan Wifi Indonesia has used the product for a minimum of roughly 3-6 months and is domiciled spread across the Jabodetabek area. Technical data is collected by a questionnaire with 5 points Likert scale, namely by reaching consumers and distributing the questionnaires, which are then processed using the SPSS program. The
\end{abstract}


results show that service quality and Price provided by PT Juragan Wifi are valid and likely met consumer expectations and criteria. Consumers of PT Juragan Wifi also have a high level of pleasure. Based on the results of hypothesis testing, it can be concluded that service quality has a positive effect on customer satisfaction, and Price has a positive impact on customer satisfaction.

Keyword: Service Quality, Price, Customer Satisfaction.

\section{INTRODUCTION}

Penetration of internet usage in Indonesia is incredibly significant, along with the expansion of social media growth, which is a new culture of people's society. The government's policy happens to stop the COVID-19 virus pandemic link by limiting community activities through Learn from Home and Work from Home, which has encouraged increased internet use in Indonesia. The increase in internet usage has made the technology industries aware while the humongous growth of demand for internet connection in Indonesia. In growing the interest for customers' internet usage, some customers are cared for and influenced by the service quality the providers provide. Alternatively, the company's evaluation report is full of complaints and suggestions regarding service in the much wider area. One aspect that is often used as a reference related to Service Quality is Price.

\section{ISP FIXED}

\begin{tabular}{lll} 
BRAND & TBI 2020 & \\
\hline IndiHome & $36.7 \%$ & TOP \\
First Media & $23.1 \%$ & TOP \\
Biznet & $8.2 \%$ & \\
Indosat M2 & $4.5 \%$ & \\
\hline
\end{tabular}

Figure 1. Top Brand Index ISP Indonesia Source: topbrand-award.com/top-brand-index/, 2021

In 2020, there are four top brand internet service providers (ISPs) based on topbrandaward.com, namely: Indihome by $36.7 \%$, First Media by $23.1 \%$, Biznet by $8.2 \%$, and 
Indosat M2 by 4.5\%. Under these circumstances, customers play an essential role as profit generators, core business strategies, and brand ambassadors. Due to the essential functions that customers play in the business, companies need to maintain customer satisfaction.

Based on the understanding above, Customer satisfaction, according to (Paul 2016) a mind of a person that adjusts the output of customer's expectancies by adjusting prepurchase of goods or services with the quality of post-purchase. Customers will be full of pleasure when they are amused and excited by their post-purchase output with no issues in achieving goals. It can be assured that pleased customers will stay in touch and keep in contact with the corporation and keep purchasing the products and services more often than customers who are not delighted, which has already been described by (Paul 2016). One of the elements that affect customer satisfaction in Service Quality. Service Quality is a particular feature of products and services in having the possibility to meet and comply with customer's motives to buy a company's products and services Kotler \&Armstrong (2014). To comply with such reasons is to make it consistent with the quality of a specific service.

Research conducted by Ekasari (2019) shows that Service Quality has a positive effect on customer satisfaction. Based on the recent issue of PT Juragan Wifi Indonesia within the company's evaluation report, It is found that customers complain that the internet network is likely unstable during lousy weather. It is also found that customers complain about slow internet maintenance services and less empathy by its employee staff while performing maintenance. The importance of service quality is seen by empathy and how friendly the staff is in solving problems that customers are facing.

Following Service Quality, the next element that affects customer satisfaction is price. According to William J. Stanton in Angipora (2002), price is the total of money required to acquire some of the product's combinations and its services to take the benefits and conformity of goods or services.

Research conducted by Oxtafiani \& Widowati (2017) shows that price has a positive effect on customer satisfaction. Based on the recent issue of PT Juragan Wifi Indonesia within the company's evaluation report, it is found that customers complain about the benefits are not conformed with the price due to the frequently unstable network, which 
comes in handy from disruptions such as bad weather and signal, which is making it looks more expensive in the customer's point of view.

In general, The importance of customer satisfaction as the key to winning the business competition has long been realized by PT. Juragan Wifi Indonesia, which is one of the internet service providers which still relatively new in Indonesia. PT. Juragan Wifi Indonesia is one of the internet service providers and as an IT solution company that specializes in providing network solutions, system integration, internet service provider networks, and data center consulting - having accomplished with a mission to facilitate the ease of IT solutions. PT. Juragan Wifi also helps build a network infrastructure with a very affordable price and package compared to its competitors, in order to make it easier for customers to reach the world of new sustainable technology.

Furthermore, due to tight competition in the internet service providers within the fact namely the increase of internet consumers in Indonesia throughout the Covid-19 pandemic, customer satisfaction has made the key to winning the current competition. Based on the facts and research aforementioned, and also the importance of service quality, price, and customer satisfaction of customers for a company, authors are greatly fascinated in holding a research study known and titled as The Influence of Service Quality, and Price on Customer Satisfaction at PT. Juragan Wifi Indonesia. The various objects, locations, and research methods carried out by various researchers make the study of all variables in another unique way of research.

\section{LITERATURE REVIEW}

\section{Customer Satisfaction}

Customer satisfaction, according to (Paul 2016) a mind a person that adjusts the output of customer's expectancies by adjusting pre-purchase of goods or services with the quality of post purchase. Customers will be full of pleasure when they are amused and excited by their post-purchase output with no issues in achieving goals. And this is supported by Zeithaml \& Bitner (2003) that also described that satisfaction is indeed a specific reaction and perception of customers regarding the concern of demands. It has also been supported by Kotler and Keller (2012). They stated that satisfaction is a sense of enjoyment of a person or the sense of discontent resulting from adjusting a product and 
service's performance and output with their expectancies. In other words, factors affecting customer satisfaction have been specified by the measurement and dimensions of customer satisfaction. According to Kotler and Keller (2012), several factors influence customer satisfaction, namely, stay loyal, purchase the products/services the company offers, recommend the products/services the company offers, be willing to pay more, give feedback. To create highly adequate satisfied customers, companies must prioritize their customer needs.

There are also several kinds of ways classification to measure customer satisfaction according to Kotler and Keller (2012), namely customer's grievance and recommendation system, Ghost/Mystery shopping, Lost Customer Analysis, the survey of satisfaction.

To determine the level of customer satisfaction, five major elements should a company take into consideration with according to Lupiyoadi (2009), namely Quality of Product, Quality of Service, Emotional Element, Charge, and Value.

\section{Service Quality}

According to Kotler and Armstrong (2014), Service Quality is a particular feature of products and services in having the possibility to meet and comply with customer's motives to buy a company's products and services. To comply with such motives is to conform and be consistent with the quality of a specific service. By all means, Service quality must be commenced with consumer needs and ended with customer satisfaction and positive perceptions of service quality.

Furthermore, According to Parasuraman, Berry, \& Zeithaml (1990: 1991) in Rezaei et al. (2018), Service Quality is a measurement of discrepancy and diversity among the expectancies of service and perceived service. Based on the explanation above, when customers expect more than service quality provided, the number of dissatisfied customers will skyrocket. A particular dissatisfaction can be found by looking at what customers will do next as if they are still with the products and services or not. Therefore, Service Quality is made by the judgment of customers within evaluations. There are many conceptual models to measure Service Quality, with one of the references applied inside this research study is the Parasuraman, Berry, and Zeithaml (PBZ) service quality model, which has long been known and still used today also known as SERVQUAL (service quality). 
The SERVQUAL dimension, according to Parasurmanan, Berry, \& Zeithaml (1990: 1991) in Rezaei et al. (2018), consists of Tangibles, Reliability, Responsiveness, Assurance, and Empathy. Meanwhile, According to Solimun \& Fernandes (2018), the concept of quality relies on the point of view applied to specify its traits, features, and detail of specs given. Three quality orientations should be consistent and conformable one way or the other, namely, consumer's point of view, products/services, and legal action.

\section{Price}

Price, according to William J. Stanton in Angipora (2002), is the amount of money required to obtain some combination of a product and the accompanying service. Meanwhile, according to Kotler and Armstrong (2012) total of money is needed to acquire some of the product's combinations and its services to take the benefits and conformity of goods or services. Amount of value customers desire to trade based on such suitability and conformity with the help of using a product or service.

Another expert opinion Tjiptono (2010), explains that price is a component that directly affects company profits. Price is solely a particle of the marketing mix which generates profit and earnings for the corporation. Price is stated in several variant names, namely sponsorship or endowment, value cost, lease, profit interest, premium, commission, fee, salary, honorarium, tuition fees, etc.

According to Stanton (1998), price indicators are listed as follows: price affordability, price competitiveness, price compatibility with product/service quality, conformity with product/service benefits.

Based on the statement above, it can be concluded that price will be created when there is conformity and compatibility with the product and service quality that the company provides to generate customer satisfaction intact.

\section{Conceptual Framework}

H1: Service Quality affects Customer Satisfaction

Ekasari's (2019) research shows that Service Quality has a significantly positive effect on Customer Satisfaction. Similar results found in the study conducted by Paul (2016) Service Quality has a positive impact on customer satisfaction as overall satisfaction. Also, research conducted by Imansyah \& Irawan (2018) which each of research shows 
that service quality has a positive effect on Customer Satisfaction. Research conducted by Damarshari, Akhmad, and Joko (2019) shows that service quality positively influences customer satisfaction. Last but not least, research conducted by Latif Abdulridha Atiyah (2017) shows that Service Quality significantly affects customer satisfaction and thus can affect the success of the organization and its ability to implement its plans and programs to achieve its objectives and t final purposes efficiently and effectively.

H2: Price affects Customer Satisfaction

Research conducted by Christianto, Ronald, \& Amelia (2020) shows that Price has a positive effect on customer satisfaction. Consumers expect that the sacrifice costs incurred to obtain services must be in accordance with and conformed with the value of benefits received by consumers. Research conducted by Yulisetiarini \& Prahasta (2019), and Delima, Ashary, \& Usman (2019) that Price has a positive and significant effect on customer satisfaction where an affordable price will increase customer satisfaction.

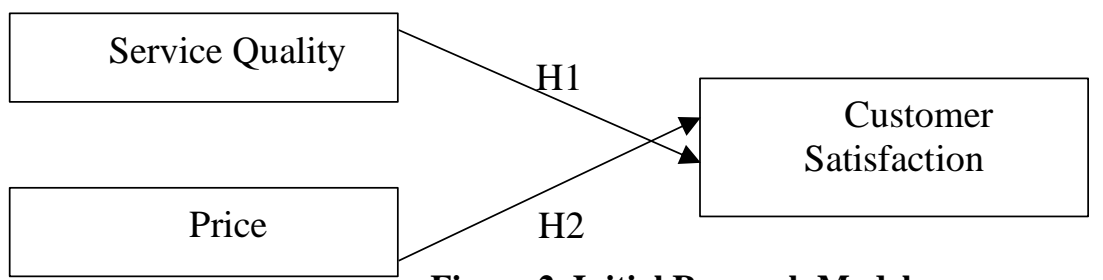

Figure 2. Initial Research Model

Source : Data proccesed by author (2021)

\section{RESEARCH METHOD}

According to Sugiyono (2014), A population is stipulated as a leveling area generally consists of all subject and object which possesses particular grades and traits should researcher to determine, to build a relatively elaborative conclusion. According to Khrishnaswamy et al.(2009), A sample is used when it is impossible or impractical to make all possible observations of the phenomenon being studied. The entire group of the study object is called population. The population of this study is the customers of PT Juragan Wifi Indonesia spread across the Jabodetabek area that is remotely active within 3-6 months subscription. A Sample is a number or total and the characteristics which are possessed by the population. The whole samples in this study are 100 customers of PT. Juragan Wifi Indonesia that spread across Jabodetabek areas. According to Ahmad 
Tohardi (2019), survey research needs a minimum of the sample as low as 100 samples or using Total Sampling, which means all the population elements become samples. There are two techniques of sampling; probability and non-probability. The determination of the sampling technique in this particular research is a non-probability sampling technique, which is a sampling technique that does not serve similar and on par opportunities for every member that needs to be chosen and picked as a sample (Sugiyono, 2014). Meanwhile, to determine the number of samples, the researcher used the purposive sampling technique, which signifies a sampling technique with reasonably specific respondents in order to create unbiased results. Therefore, the total sample, which was deliberately confirmed and assigned by certain criteria, has been determined by the author to get a representative sample according to (Sugiyono 2014). By all means, the unbiased result can occur if the sample does not properly fulfill the criteria that the researcher previously confirmed and assigned to emphasize its research study. The data analysis technique in this study is analyzed by the SPSS version 22 program with various environmental tests. The measurement scale in this study uses a 5 point Likert scale which is a measurement that gives a score of 1-5. According to Sugiyono (2014), the 5 points of the Likert scale are indeed applied to quantify these specific cases such as behavior, assumption, and point of view in a particular individual or people about the social phenomenon that occurs in the society. Application of the 5 points Likert scale is applied in consequence of convenience for respondents in answering each question with choices in the following order: strongly disagree, disagree, neutral, agree, and strongly agree.

The data collection technique used in this study is primary data. Sugiyono (2014) stated that primary data is a particular input that is collected from the primary data source and immediately provided to collectors. Simply put, It is a specific input that is precisely acquired from research subject and object by survey, polling, etc. For collecting primary data, the researcher applied a survey as a method by using a questionnaire that has previously been set up by operational variable and immediately makes a distribution to the respondents. Respondents who were not interested and met the researcher's criteria supposedly to leave the questionnaire off. 


\section{RESULT AND DISCUSSION}

On the Statistic Descriptive, Strongly Agree is the option most preferred by the respondents compared to other options, namely $60.00 \%$ with the statement "I am ready and compliant to pay over to all products and services of PT Juragan Wifi Indonesia." This result indicated that customers would be ready and compliant to pay over for services that PT. Juragan Wifi Indonesia offered and served. With the various advantages provided by PT. Juragan Wifi Indonesia, customers feel that they are satisfied with something they get from the company. The increase of service cost must be balanced with an increase in service quality so that the company can maintain the loyalty of customers from this circumstance (Kotler \& Keller, 2009).

Overall, Strongly Agree is the option most chosen and preferred by respondents compared to other options, namely $65.00 \%$ with the statement "PT Juragan Wifi Indonesia does have complete service facilities."

This result indicated what customers feel PT Juragan Wifi Indonesia has a complete service facility. It can be concluded that most customers are happy enough and agree that Juragan Wifi has full service facilities. Also, by looking through the provision of uniformed employees and officers in serving customers at the company's location/office, which is showing a high intention regarding tangibles, empathy, and responsiveness (Parasuraman, Berry \& Zheitaml, 1990). On the other hand, regarding facts in the field, the company also often holds various reward programs for its loyal customers. This program is believed to be a manifestation of the company's seriousness in serving customers.

Overall, Strongly Agree is the option most preferred by respondents compared to other options, namely $62.00 \%$ with the statement "price of products and services at PT Juragan Wifi Indonesia are worth it and beneficial to consumers."

This result indicated what customers feel about the price of the quality and services of the company is likely appropriate and fit with the benefits received to customers (William J Stanton, 1998). The various benefits of service facilities provided by the company can be used by customers properly so that the help of a product/service can be directly felt by customers. It also means that PT Juragan Wifi can educate customers about the various benefits of services which the company has provided to customers. 
Table 1. Multiple Linear Regression test Results

Coefficients $^{\mathrm{a}}$

\begin{tabular}{|c|c|c|c|c|c|}
\hline \multirow[b]{3}{*}{ Model } & & & & & \\
\hline & \multicolumn{2}{|c|}{ Unstandardized Coefficients } & \multirow{2}{*}{$\begin{array}{c}\text { Standardized } \\
\text { Coefficients } \\
\text { Beta }\end{array}$} & \multirow[b]{2}{*}{$\mathrm{t}$} & \multirow[b]{2}{*}{ Sig. } \\
\hline & $\mathrm{B}$ & Std. Error & & & \\
\hline 1 (Constant) & 4.796 & 2.029 & & 2.363 & .020 \\
\hline Service Quality & .603 & .091 & .548 & 6.594 & .000 \\
\hline Price & .205 & .085 & .202 & 2.427 & .017 \\
\hline
\end{tabular}

a. Dependent Variable: Customer Satisfaction

Source : Data proccesed by author (2021)

The formulation of the hypothesis and the decision-making criteria are:

Formulation of Hypothesis $1(\mathrm{H} 1)$

Hypothesis 1:

Ho: Service Quality does not have significantly positive effect on Customer Satisfaction

Ha: Service Quality does have significantly positive effect on Customer Satisfaction

Formulation of Hypothesis $2(\mathrm{H} 2)$

Hypothesis 2:

Ho: Price does not a significantly positive effect on Customer Satisfaction

Ha: Price does have a significantly positive effect on Customer Satisfaction



Figure 2. Research Model

Source : Data proccesed by author (2021)

The basis of decision making is to compare $t$ count with $t$ table as follows:

H1: The variable of Service Quality has a t count value of 6.594. The t count value of the Service Quality variable is subsequently matched with the value of the $t$ table either the $t$ count value supports or does not support. Thus, to make sure the decision, the $\mathrm{t}$ count $>\mathrm{t}$ table is 6,594>1,984. The significance of the Service Quality variable is 0.000 and below 0.05. It can be deduced and interpreted that Ho has been rejected and Ha has been 
accepted. Thus, Service Quality has a significant and positive effect on Customer Satisfaction. These results follow the research conducted by Ekasari(2019) and Damarshari, Akhmad, and Joko (2019), which stated that Service Quality has a positive or significant effect on customer satisfaction.

$\mathrm{H} 2$ : The price variable has a tcount value of 2.427. The t count value of the Price variable is subsequently matched with the t table value. Thus, to make sure the decision, the $t$ count $>\mathrm{t}$ table is $2.427>1.984$. The significance of the Price variable is 0.017 and below 0.05 . It can be deduced and interpreted that Ho has been rejected and Ha has been accepted. Thus, the price also has a positive and significant effect on Customer Satisfaction. These results follow the research conducted by Christianto, Ronald, \& Amelia (2020), Yulisetiarini \& Prahasta (2019), and Delima, Ashary, \& Usman (2019), which stated that price has a positive and significant effect on customer satisfaction.

Refer to the Table 1, the linear regression has been resembled and obtained $\mathrm{Y}=4.796+$ $0.603 \mathrm{X} 1+0.205 \mathrm{X} 2$. The meaning of the figures in the above equation is as follows: The regression coefficient value of the Service Quality variable is relatively high and positive, namely 0.603. It can be interpreted and drawn a conclusion as for each one gain in Service Quality score, and it will also gain Customer Satisfaction to 0.603 scores with a fixed variable. Meanwhile, The regression coefficient value of the Price variable is relatively high and positive, namely 0.205 . It can be interpreted and drawn a conclusion as for each one increase in Price score will increase Customer Satisfaction by 0.205.

Next, The normality test data purposely intend to establish and set the partition of a particular data so that the data can be normal and well-distributed upon to entire variables taken in the study. In this study, statistical tests are applied for detection whether the residuals are well distributed or not by using the normality data test with the KolmogorovSmirnov test, namely by matching the Kolmogorov value calculation with the value of the Kolmogorov table. The test needs to be done to test whether there is a normal distribution or not in all the variables. Decision-making criteria are as follows: The normal data distribution or The abnormal/not normal data distribution. 
The outputs of the Kolmogorov-Smirnov test can be seen in the table below:

Table 2. Normality Data Test Results

1-Sample Kolmogorov-Smirnov Test

\begin{tabular}{lll} 
& & $\begin{array}{l}\text { Unstandardized } \\
\text { Residual }\end{array}$ \\
\hline $\mathrm{N}$ & & 100 \\
\hline N. Parameters & & \\
& Mean & .0000000 \\
\hline Most Extreme Differences & Std. Deviation & 2.22618151 \\
\cline { 2 - 3 } & Absolute & .115 \\
\hline Positive & .067 \\
\hline Test Statistic & Negative & -.115 \\
\hline Asymp. Sig. (2-tailed) & & .115 \\
\hline
\end{tabular}

a. Test distribution is Normal.

b. Calculated from data.

c. Lilliefors Significance Correction.

Source: Processed by researchers, 2021

Refer to the outputs of the Kolmogorov-Smirnov test shown above using the standard residual value method, and In Table 2, It is shown that the calculated Kolmogorov value calculation is scored 0.115 . The normal distribution value of the Kolmogorov table with the total of respondents in the number of 100 respondents is 0.134 . Thus, the value of the calculated Kolmogorov in this research is $(0.115)<$ the value of the table Kolmogorov (0.134) so, It is well interpreted that Ho has been accepted and the entire data in this research study is well and ordinary normal distributed. By all means, entire occupants and respondents are correspondingly normal.

Next, The Multicollinearity test aims to verify and examine the relationship among entire independent variables. Model regression which the researcher wishes to find out is a specific model which does not have a relation among its entire independent variables. Multicollinearity can be easily interpreted and withdrawn its conclusion by viewing each value of tolerance value and its opposite VIF value. These two measuring instruments show each independent variable which is evidently clarified and defined by other independent variables. The value which is broadly applied to represent the absence of aggravating multicollinearity is the value of tolerance must be $\geq 0.10$ or else in another 
version, it must be on par with the VIF value, which asserts that each variable must be $\leq 10$.

The results of the Multicollinearity test can be viewed and considered from the table shown below.:

Table 3. Multicollinearity Test Results



a. Dependent Variable: kepuasan pelanggan

Source: Processed by researchers, 2021

Refer to table 3 above, on the right corner, the outputs of the multicollinearity test shown and exhibited above indicate the value of tolerance through entire independent variables is above 0.10 , namely 0.864 , and the value of VIF for each independent variable is below 10 , namely 1.157 . It can be interpreted that no correlation is found among all independent variables so that the model of regression delivered from this research study is adequately capable of being applied to make an estimation and forecast regarding the effect between the independent and dependent variables.

Next, The heteroscedasticity test eminently intends to verify and examine if there is a dissimilarity that causes each observation to another of the residual in model regression variance applied is not entirely equal. If the value of variance from each residual of one to the other observation is properly disparate, it is well known as homoscedasticity, and then if it is not properly disparate one to the other, it is well known as heteroscedasticity. To create and build a model regression is one with homoscedasticity and the other is with no heteroscedasticity with the sign of dot points spread above the zero lines and do not mold and shape a specific scheme form. 


\section{Figure 3. Heteroscedasticity Test Results using Scatter Plot \\ Scatterplot}

Dependent Variable: kepuasan pelanggan

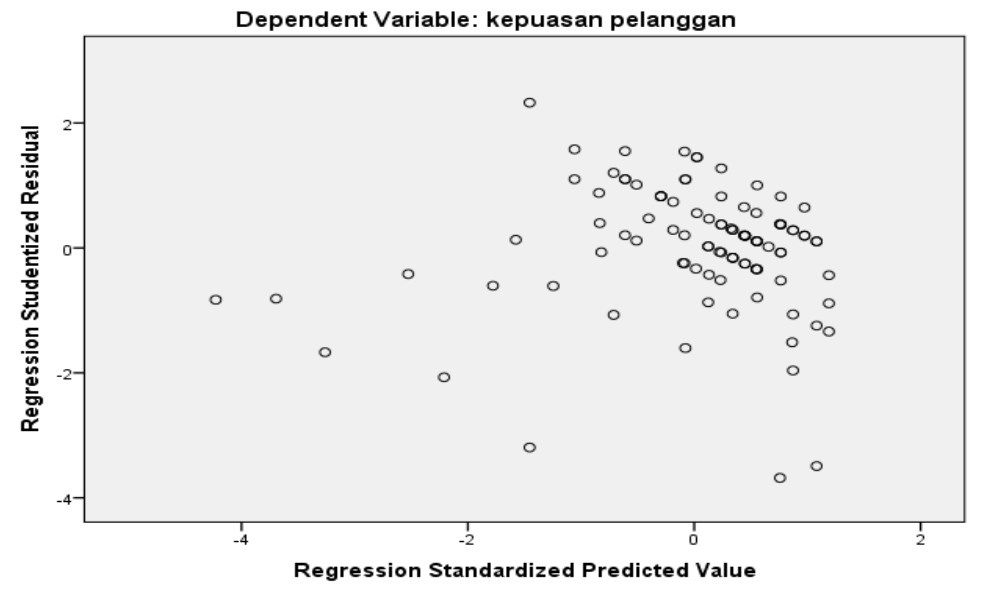

Source: Processed by researchers, 2021

Refer to Figure 3 above; its interpretation of the heteroscedasticity test results examined with a scatter plot indicates entire dot points meticulously maintain and spread above the zero lines and do not mold and shape a specific scheme form. It can be interpreted and withdrawn conclusion that no heteroscedasticity issue is found from resulting above, which contains and explains concerning the model of regression.

\section{CONCLUSION}

Description of earlier entire variables contains Service Quality, Price, and Customer Satisfaction at PT. Juragan Wifi Indonesia: The result of the first primary hypothesis test shows that service quality has a significant and positive effect on customer satisfaction at Juragan Wifi Indonesia following the research conducted by Ekasari(2019) and Damarshari, Akhmad, and Joko (2019), which stated that Service Quality has a positive or significant effect on customer satisfaction.

The result of the second hypothesis test shows that price has a significant and positive effect on customer satisfaction at Juragan Wifi Indonesia. Following the research conducted by Christianto, Ronald, \& Amelia (2020), Yulisetiarini \& Prahasta (2019), and Delima, Ashary, \& Usman (2019), which stated that price has a positive and significant effect on customer satisfaction.

Service Quality (X1). Descriptively, most respondents preferred tangibles or entirely adequate service facilities. In the form of a particular service, assurance or guarantee of 
the staff's friendliness can affect customer satisfaction. It is hoped and expected that increasing the service facilities and the team's friendliness in serving customers can increase customer satisfaction.

The price (X2). Descriptively, most respondents preferred the conformity price with the benefits received by customers. The form of price conformity with the benefit of the product received by the customers can affect customer satisfaction. Solutions related to price to get the right price without decreasing the quality by purchasing particularly perfectly good and cheap supply product environments will also increase customer satisfaction.

Recommendations from the researcher needed to be noted, such as the necessity of conducting field studies to determine various factors that affect customer satisfaction for internet service users, such as customer demographic factors, emotional factors, and the ease of obtaining goods/services. In addition, following Service Quality of PT. Juragan Wifi Indonesia, A gain upon service quality regarding Tangibles and Assurance such as complete facilities and friendliness of the staff provided by Juragan Wifi Indonesia to customers, will definitively gain customer satisfaction to keep consistently using complete services offered and provided by Juragan Wifi Indonesia. On the other hand, upon price regarding price conformity with benefits, if there is an increase in benefits without increasing the price to customers, it will definitively increase customer satisfaction indeed. The use of different indicators and a larger number of respondents can obtain better results. also in order to make this research more competent is to expand the various elements that can affect customer satisfaction on internet service users, such as customer demographic factors, emotional factors attached to customers and the ease of obtaining goods/services. In addition, the use of different indicators and a larger number of respondents can obtain better results.

The research limits few factors that affect Customer Satisfaction. Regarding the limitations of research carried out during the Covid-19 pandemic, so that it still lacks information obtained by the researcher, it is hoped that in the future, other studies will find more information related to the problems that occur. The limitation of research carried out and conducted during the COVID-19 pandemic, lack of information obtained by researcher due to pandemic, the company can only afford 100 total samples maximum 
to become respondents, and it is still related following the statement of Ahmad Tohardi (2019) that a minimum of samples conducted for survey research is as low as 100 total samples. Few respondents do not fill it in properly honestly so that the data might be a little misdirection. The research can be re-implemented again with other independent variables in different places/research objects or using other variables in accordance with the issues that occur in the object of research.

\section{REFERENCES}

Albari, Atika Kartikasari. 2019. The Influence of Product Quality, Service Quality and Price on Customer Satisfaction and Loyalty. Asian Journal of Entrepreneurship and Family Business, Vol. III No. 01, 49-64

Angipora, Marius P. 2002. Dasar-Dasar Pemasaran. Jakarta: PT.Raja Grafindo Persada. Atiya, Latif Abdulridha h. 2017. Impact of service quality on customer satisfaction. Australian Journal of Basic and Applied Sciences, 11(5) April 2017, Pages: 20-28

Bitner, M. J. dan Zeithaml, V. A., 2003, Service Marketing (3rd ed.), Tata McGraw Hill, New Delhi.

Blocker, Christopher P. 2011. Modeling customer value perceptions in cross-cultural business markets. Journal of Business Research 64. 533-540

Christianto, Ricky., Ronald., \& Amelia. 2020. Product Quality, Service Quality and Price Effect on Customer Loyalty through Customer Satisfaction (Studied of Honda Mobilio Car Users in Surabaya). International Journal of Economics \& Business. ISSN: 2717-3151, Volume 7, Issue 1, page $34-42$

Damarsari, Akhmad, and Joko. 2019. The Effect of Service Quality on Customer Satisfaction at PT. Lotus Indah Textile Industry. ISSN : 2597-4785, Vol. 2

Delima, Ade and Ashary, Hajar Mareti and Usman, Osly. 2019. Influence of Service Quality, Product Quality, Price, Brand Image, and Promotion to Consumer Satisfaction Affecting on Consumer Loyalty (Online Shop) Available at SSRN: https://ssrn.com/abstract=3308707 diakses 2 Januari 2021

Dodds, B. 2003. Managing customer value: Essentials of product quality, customer service, and price decisions. University Press of America. 
Ekasari, Ratna., et.al. 2019. Effect of Price, Product Quality, and Service Quality on Customer Satisfaction on Online Product Purchases. IOP Conf. Series: Journal of Physics: Conf. Series 1175 (2019) 012287. IOP Publishing

Fatimah, Nur Hadziqotul., \& Ratnasari, Ririn Tri. 2015. Pengaruh Bauran Pemasaran Jasa Terhadap Nilai Dan Niat Berperilaku Pelanggan Hotel Syariah Grand Kalimas Di Surabaya. JEBIS Vol. 1, No. 2. 117-142

Ghozali, Imam. 2011. Aplikasi Analisis Multivariate Dengan Program SPSS. Semarang: Badan Penerbit Universitas Diponegoro

Hakim, Lukmanul., Susanti, Nanis., \& Ujianto. 2017. Influence of Customer Relationship Management, Brand Equity, Perceived Product Quality, Perceived Price on Customer Value and Purchase Intention (Studies Philips Light Bulb in Batam). International Journal of Economics and Finance; Vol. 9, No. 7. 122-131

Hayati, S. 2016. Pengaruh Kualitas Pelayanan Dan Harga Terhadap Nilai Pelanggan Dan Terhadap Kepuasan Penggunaan Jasa Service (Studi Kasus Pada Bengkel Seruyan Motor). Jurnal Terapan Manajemen dan Bisnis (2/2), 68-82

Hair, Jr et.al. (2010). Multivariate Data Analysis (7th ed). United States: Pearson Hutama, Dhagat Wihasta., \& Widiyanto, Ibnu. 2015. Nilai Pelanggan Dan Minat Loyalitas. Diponegoro Journal of Management, Volume 4, Nomor 4, Tahun 2015, Halaman 1-10

Irawan, Ferdi., Gerry Suganda, Innocentius Bernarto. 2018. The Influence of Service Quality and Customer Satisfaction toward Customer Loyalty. E - Proceeding International Conference in Innovative Business and Entrepreneurship. 7 May 2018. Thailand: Rangsit University

Imansyah., \& Irawan, Haris. 2018. Pengaruh Kualitas Pelayanan Terhadap Kepuasaan Pelanggan Pada Karaoke Inul Vizta Tanjung. Jurnal Ilmiah Ekonomi Bisnis. Jilid 4 Hal 319 - 329

Khrishnaswamy K.N. 2009. Management Research Methodology. New Delhi. Dorling Kindersley.

Kotler, Philip dan Kevin Lane Keller. 2009. Manajemen Pemasaran. Jilid I. Edisi ke Tigabelas. Jakarta: Erlangga 
Kotler, Philip dan Kevin Lane Keller. 2012. Manajemen Pemasaran. Edisi 13, Jilid 2. Jakarta: Erlangga

Kotler, Philip dan Armstrong, Gary. 2012. Principles of Marketing. New Jersey: Prentice Hall.

Kotler, Philip and Armstrong, Gary. 2014. Principle of Marketing, Fifteen Edition. Published by Pearson Education Limited. England

Kuncoro, Bayu Angga Aryo., Fauzi, Achmad., \& Arifin, Zainul. 2017. Analisis Pengaruh Kesadaran Merek, Persepsi Kualitas, Asosiasi

Merek Dan Loyalitas Merek Terhadap Nilai Pelanggan

(Survei pada Pelanggan Produk Aqua 600ml di Indomaret Jl. Raya Candi V Malang). Jurnal Administrasi Bisnis (JAB)|Vol. 51 No. 1 Oktober 2017

Kurniawan, Hendy., Soesanto, Harry., \& Yuniawan, Ahyar. 2016. Pengaruh Kualitas Produk, Kualitas Layanan, Dan Persepsi Harga Terhadap Nilai Pelanggan Dalam Meningkatkan Minat Beli (Studi Pada Konsumen Produk Batu Potong Besi 4 Inch Merek Wd Di Jawa Tengah). Jurnal Sains Pemasaran Indonesia, Volume XV, No. 1, Mei 2016, halaman 46-61

Lupiyoadi, Rambat. 2009. Manajemen Pemasaran Jasa: Berbasis Kompetensi. Edisi 1. Jakarta: Salemba Empat

Paul, Justin. 2016. Impact of service quality on customer satisfaction in private and public sector banks. International Journal of Bank Marketing Vol. 34 No. 5, pp. 606-622

Mahmoud, Mahmoud Abdulai., Hinson, Robert E.., \& Anim, Patrick Amfo. 2017. Service innovation and customer satisfaction: the role of customer value creation. European Journal of Innovation Management Vol. 21 No. 3, 2018 pp. 402-422

Munisih, Siti., \& Soliha, Euis. 2015. Pengaruh Kualitas Produk Terhadap Nilai Pelanggan Dan Kepuasan Pelanggan Dan Dampaknya Pada Loyalitas Pelanggan Apotek Dela Semarang. Prosiding Seminar Nasional \& Call for Papers. Kinerja Perbankan, Bisnis dan Ekonomi Indonesia Menghadapai Asean Economic Community 2015. Fakultas Ekonomika Dan Bisnis Universitas Stikubank Semarang

Oxtafiani, Neni \& Widowati, Sri Yuni. 2017. Analysis Of Effect Of Service Quality, Quality Products, And Prices On Customer Satisfaction (Case Study At PT 
Asuransi Tri Pakarta Customer Branch Semarang). Economics \& Business Solutions Journal Volume 1, Number 1, 35-44

Razak, Ismail., Nirwanto, Nazief \& Triatmanto, Boge. 2016. The Impact of Product Quality and Price on Customer Satisfaction with the mediator of Customer Value. Journal of Marketing and Consumer Research Vol.30. 59-68

Rezaei, Jafar., Kothadiya, Oshan., Tavasszy, Lori., Kroesen, Maarten. 2018, Quality assessment of airline baggage handling systems using SERVQUAL and BWM. Tourism Management 66 (2018) 85-93

Sánchez-Gutiérrez, José., et.al. 2019. The impact on competitiveness of customer value creation through relationship capabilities and marketing innovation. Journal of Business \& Industrial Marketing 34/3 (2019) 618-627

Sara Leroi-Werelds. 2019. An update on customer value: state of the art, revised typology, and research agenda. Journal of Service Management. Vol. 30 No. 5, pp. 650-680

Solimun, S. and Fernandes, A.A.R. (2018), "The mediation effect of customer satisfaction in the relationship between service quality, service orientation, and marketing mix strategy to customer loyalty", Journal of Management Development, Vol. 37 No. 1, pp. $76-87$

Suhendra, Garit., \& Yulianto, Edy. 2017. Pengaruh Kualitas Layanan Terhadap Nilai Pelanggan Dengan Kepuasan Sebagai Variabel Mediator (Survei pada Pelanggan Bukalapak.com). Jurnal Administrasi Bisnis (JAB)|Vol. 51 No.2, Oktober 2017

Stanton, Wiliam J. 1998. Prinsip Pemasaran. Edisi Ketujuh Jilid 1. Jakarta: Erlangga

Sugiyono. 2014. Metode Penelitian Kuantitatif Kualitatif dan R\&D. Bandung: Alfabeta Suliyanto. 2011. "Ekonometrika Terapan: Teori Dan Aplikasi Dengan SPSS”. Edisi 1. Yogyakarta: ANDI Yogyakarta

Tjiptono, Fandy. 2010. Strategi Pemasaran, Edisi III, Yogyakarta : CV. Andi Offset Tjiptono dan Chandra (2011) Service, Quality and Satisfaction (Ed 3). Yogyakarta. Andi. Tjiptono,Fandy. 2014. Pemasaran Jasa (Prinsip, Penerapan, Penelitian). Yogyakarta. Andi.

Tjiptono, Fandy. 2016. Pemasaran Jasa (Prinsip, Penerapan, Penelitian). Yogyakarta. Andi. 
Tohardi, Ahmad. 2019. Pengantar Metodologi Penelitian Sosial. Tanjungpura. Tanjungpura Univeristy Press.

Yulisetiarini, Diah., \& Prahasta, Yongky Ade. 2019. The Effect Of Price, Service Quality, Customer Value, And Brand Image On Customers Satisfaction Of Telkomsel Cellular Operators In East Java Indonesia. International Journal Of Scientific \& Technology Research, Volume 8, Issue 03, 5-9

www.topbrand-award.com/top-brand-index/?tbi_index=Top\%20Brand\&tbi_year=2020) (accessed 11 January 2021) 